\title{
UPAYA MENINGKATKAN HASIL BELAJAR PENDIDIKAN KEWARGANEGARAAN MELALUI STRATEGI PEMBELAJARAN COOPERATIVE LEARNING TIPE TEAM GAME TURNAMEN (TGT)
}

\author{
Oleh: Etin Solihatin*
}

\begin{abstract}
The purpose of this research is to improve learning outcomes through Cooperative Learning Civics Team Type Game Tournament (TGT) and promote cooperation among the students. Research methods Classroom Action Research by 3 cycles. The results of the study in the first cycle an average score of 62.6 students, with an increase of $12.64 \%$. Cycle II scores an average of 74.07, with a gain of 33.21\%. Cycle III students' average scores

amounted to 82.9, with an increase of 49.16\%. Type TGT Civics can improve learning outcomes by $49.16 \%$. So learning outcomes Civics increased by $49.16 \%$ by using Cooperative Learning Type TGT.
\end{abstract}

Key Words: Cooperative Learning Type Team Games Tournament (TGT), Results Learning, Civic Education.

\section{PENDAHULUAN}

\section{Latar Belakang Masalah}

Memperhatikan misi pendidikan kewarganegaraan, sebaiknya penyelenggara pembelajaran $\quad$ PKn mampu mempersiapkan, membina, dan membentuk kemampuan peserta didik yang menguasai pengetahuan, sikap, nilai dan kecakapan dasar yang diperlukan bagi kehidupan di masyarakat (Kosasih, 2000: 30). Untuk menunjang tercapainya tujuan PKn, harus didukung oleh iklim pembelajaran yang kondusif. Iklim pembelajaran yang dikembangkan oleh pendidik mempunyai pengaruh yang sangat besar terhadap keberhasilan dan kegairahan belajar peserta didik. (Wahab, 2006: 41). Kualitas dan keberhasilan pembelajaran sangat dipengaruhi oleh kemampuan dan ketepatan pendidik dalam memilih dan menggunakan strategi pembelajaran.

Berdasarkan analisis konseptual dan kondisi pendidikan kewarganegaraan $(\mathrm{PKn})$, ternyata tidak sedikit peserta didik kesulitan dalam mengikuti mata pelajaran, dikarenakan metode pembelajaran yang dipilih dan digunakan oleh pendidik dirasakan kurang tepat (Wahab, 2006: 41). Dengan demikian kemandirian peserta didik dalam belajar kurang terlatih, dan proses pembelajaran akan berlangsung secara kaku, sehingga kurang mendukung pengembangan pengetahuan, sikap, moral dan keterampilan peserta didik (Hasan, 1996:23).

\footnotetext{
* Dosen pada Program Studi Pancasila dan Kewarganegaraan, Jurusan Ilmu Sosial Politik, Fakultas Ilmu Sosial Universitas Negeri Jakarta
} 
Berdasarkan fakta di lapangan bahwa skor hasil belajar PKn rata-rata 6,8 sedangkan skor KKM 7,0, sehingga hasil belajar PKn peserta didik masih di bawah skor $\operatorname{KKM}(6,8<7,0)$. Hal ini diduga akibat pembelajaran hanya menekankan pada aspek hafalan semata. Pendidik lebih mendominasi dalam proses pembelajaran (teacher centered), kurang melibatkan peserta didik dalam proses pembelajaran, sehingga dalam pembelajaran cenderung pasif, kurang mandiri. Dengan kata lain kemandirian peserta didik dalam belajar kurang terlatih. Peserta didik dalam bekerjasama saat belajar kurang, yang sering muncul persaingan tidak sehat bukan persandingan (kerja sama) yang sangat diharapkan dalam pembelajaran PKn.

Atas dasar asumsi di atas, mungkin pendidik sudah merasa mengajar dengan baik, tetapi peserta didik tidak belajar, sehingga terjadi salah konsep antara pemahaman pendidik dalam mengajar dengan misi dari PKn sebagai mata pelajaran yang mengacu pada pembekalan pengetahuan keterampilan kepada peserta didik, sebagai bekal dalam menjalani kehidupan bermasyarakat (Sumantri, 2000: 2). Kondisi ini didukung oleh kenyataan yang ada di lapangan bahwa aspek metodologis dan pendekatan ekspositori sangat menguasai seluruh proses pembelajaran (Sumantri, 2000: 2). Dengan demikian Pendidikan Kewarganegaraan belum mampu menumbuhkan iklim yang menantang peserta didik untuk belajar berkolaborasi dengan teman, dan tidak mendukung produktivits serta mengembangkan berpikir peserta didik.

Sehubungan dengan permasalahan di atas, maka upaya peningkatan kualitas proses pembelajaran dalam Pendidikan Kewarganegaraan merupakan suatu kebutuhan yang sangat mendesak untuk dilakukan. Untuk itu rancangan pembelajaran, sebaiknya diarahkan dan difokuskan sesuai dengan kondisi dan perkembangan potensi peserta didik agar pembelajaran yang dilakukan benar-benar berguna dan bermanfaat bagi peserta didik. Salah satu strategi pembelajaran tersebut adalah Cooperative Learning tipe TGT.

\section{Perumusan Masalah}

Permasalahan dalam penelitian ini dirumuskan sebagai berikut: Apakah strategi pembelajaran Cooperative Learning Tipe TGT dapat meningkatkan hasil belajar PKn?

\section{Tujuan Penelitian}

Secara operasional penelitian ini bertujuan untuk meningkatkan hasil belajar PKn melalui strategi pembelajaran Cooperative Learning Tipe TGT. 


\section{Manfaat Penelitian}

Adapun manfaat penelitian ini antara lain : Untuk meningkatkan hasil belajar PKn melalui strategi pembelajaran Cooperative Learning Tipe TGT.

\section{KAJIAN PUSTAKA}

\section{Strategi Pembelajaran Cooperative Learning}

Cooperative mengandung pengertian bekerja bersama dalam mencapai tujuan bersama (Hamid Hasan : 2000). Dalam kegiatan kooperatif, peserta didik secara individual mencari hasil yang menguntungkan bagi seluruh anggota kelompok. Jadi belajar kooperatif adalah pemanfaatan kelompok kecil dalam pengajaran yang memungkinkan peserta didik bekerja bersama untuk memaksimalkan belajar individu dan anggota kelompok tersebut (Johnson, et.al: 2010, Hamid Hasan, 2000).

Cooperative Learning Tipe TGT lebih dari sekedar belajar kelompok atau kelompok kerja, karena belajar harus ada "Struktur dorongan dan tugas yang bersifat kooperatif, sehingga memungkinkan terjadinya interaksi secara terbuka dan hubungan-hubungan yang bersifat interdependensi yang efektif diantara anggota kelompok (Slavin, 2011; Stahl, 2010).

\section{Konsep Dasar Cooperative Learning}

Cooperative Learning. Adapun prinsip dasar tersebut menurut Stahl (2010), meliputi:

a. Perumusan Tujuan belajar peserta didik harus jelas.

b. Penerimaan yang menyeluruh oleh peserta didik tentang tujuan belajar.

c. Ketergantungan yang bersifat positif

d. Interaksi yang bersifat terbuka

e. Tanggung jawab individu,

f. Kelompok bersifat heterogen

g. Interaksi sikap dan perilaku sosial yang positif.

h. Tindak Lanjut

i. Kepuasan dalam belajar.

\section{Langkah-Langkah dalam Strategi Cooperative Learning Tipe TGT}

Langkah-langkah dalam penggunaan strategi Cooperative Learning secara umum (Stahl, 2004), dapat dijelaskan sebagai berikut:

a. Merancang rencana pembelajaran

b. Dalam aplikasi pembelajaran di kelas, pendidik merancang lembar observasi

c. Dalam melakukan observasi terhadap kegiatan peserta didik

d. Pendidik memberikan kesempatan kepada peserta didik dari masingmasing kelompok untuk mempresentasikan hasil kerjanya. 


\section{Team Game Turnamen (TGT)}

Komponen-komponen TGT adalah sebagai berikut (Robert E. Slavin, 2010: 177) :

1. Presentasi di kelas

- Game terdiri atas pertanyaan yang kontentanya relevan dengan yang dirancang untuk menguji pengetahuan.

- Turnamen adalah sebuah struktur dimana game berlangsung. Biasanya berlangsung pada akhir unit (Robert E. Slavin, 2010: 166).

- Menempatkan para peserta didik ke dalam tim.

\section{Belajar dan Pembelajaran}

Masalah belajar adalah masalah yang selalu aktual dan dihadapi oleh setiap orang. Usaha dan keberhasilan belajar seseorang dipengaruhi oleh faktor yang bersumber pada dirinya dan di luar dirinya atau lingkungannya (Sukmadinata, 2003: 162-163).

Mayer dalam Charles M. Reigeluth mengemukakan pengertian belajar telah berkembang dalam tiga pandangan. Pertama, belajar terjadi ketika peserta didik memperkuat atau memperlemah hubungan antara stimulus dan respons. Kedua, belajar sebagai penambahan pengetahuan. Hal ini didasarkan pada ide bahwa belajar terjadi ketika peserta didik menempatkan informasi dalam long-term memory. Ketiga, belajar sebagai mengkonstruksi pengetahuan. Hal ini didasarkan pada ide bahwa belajar terjadi ketika peserta didik aktif mengkonstruksikan pengetahuan (Mayer, 2010: 143).

Menurut Gredler bahwa belajar adalah proses seseorang memperoleh berbagai kecakapan, keterampilan, dan sikap. Belajar adalah perubahan dalam disposisi manusia atau kapabilitas yang dicapai selama waktu tertentu dan tidak semata-mata disebabkan oleh proses pertumbuhan. Perubahan tersebut merupakan perubahan tingkah laku manusia yang dapat diinferensikan dengan membandingkan tingkah laku sebelum dikondisikan dalam situasi belajar dengan tingkah laku yang ditunjukkan setelah adanya perlakuan (Gredler, 2011: 188-189).

Belajar memerlukan keterlibatan secara aktif orang yang belajar, sehingga mereka akan lebih mampu mengenal dan mengembangkan kapasitas belajar dan potensi yang dimiliki secara penuh, menyadari dan dapat menggunakan potensi sumber belajar yang terdapat di sekitarnya (Dimyati \& Mudjiono, 2002: 115-117).

Dalam konsep teknologi pendidikan, dibedakan istilah pembelajaran (instruction) dan pengajaran (teaching). Pembelajaran, disebutkan juga kegiatan pembelajaran atau instructional adalah usaha mengelola 
lingkungan dengan sengaja agar seseorang membentuk diri secara positif tertentu dalam kondisi tertentu. Sedangkan pengajaran adalah usaha membimbing dan mengarahkan pengalaman belajar kepada peserta didik yang biasanya berlangsung dalam situasi resmi/ formal (Miarso, 2004: 528)

Menurut Undang-undang No. 20 tahun 2003, Pasal 1 bahwa pembelajaran adalah proses interaksi peserta didik dengan pendidik dan sumber belajar pada suatu lingkungan belajar. Romiszowski mengemukakan bahwa pembelajaran adalah suatu perangkat kegiatan yang mempengaruhi orang yang belajar sedemikian rupa sehingga terjadinya proses pembelajaran (Romiszowski: 2011: 110-126).

Berdasarkan uraian-uraian di atas, maka terdapat empat hal yang penting dalam belajar (learn) yakni; (1) belajar merupakan suatu proses perubahan tingkah laku akibat pengalaman/latihan yang dilakukan secara sadar; (2) perubahan dalam belajar bukan bersifat sementara (relatif menetap); (3) belajar merupakan perubahan tingkah laku yang bersifat positif dan memberikan manfaat bagi individu; (4) belajar merupakan perubahan yang terarah dalam mencapai tujuan tertentu.

\section{Pendidikan Kewarganegaraan (PKn)}

Berdasarkan penjelasan pasal 37 ayat (1) Undang-undang RI No. 20 tahun 2003: Pendidikan kewarganegaraan dimaksudkan untuk membentuk peserta didik menjadi manusia yang memiliki rasa kebangsaan dan cinta tanah air (UU RI No. 20, tahun 2003: 6)

Menurut Minto Rahayu (2010: 17) mengatakan hakikat Pendidikan Kewarganegaraan (PKn) bertujuan membekali dan memantapkan dengan pengetahuan dan kemampuan dasar hubungan warga negara Indonesia yang Pancasilais dengan negara dan sesama warga negara. Dengan kemampuan dasar, diharapkan mampu menerapkan nilai-nilai Pancasila dalam kehidupan sehari-hari, memiliki kepribadian yang mantap, berpikir kritis, bersikap rasional, estetis dan dinamis, berpandangan luas, bersikap demokratis dan berkeadaban.

\section{Hasil Belajar Pendidikan Kewarganegaraan (PKn)}

Gagne, Briggs dan Wager mengemukakan bahwa hasil belajar dapat diamati melalui kinerja peserta didik. Terdapat lima jenis hasil belajar yaitu (1) keterampilan intelektual, yakni suatu kemampuan membuat seseorang menjadi kompeten terhadap suatu subjek sehingga mereka dapat mengelompokkan, mengidentifikasi, 
70 JURNAL ILMIAH MIMBAR DEMOKRASI

mendemonstrasikan dan menggeneralisasikan suatu gejala, (2) strategi kognitif, yaitu kemampuan seseorang untuk dapat mengontrol aktivitas intelektualnya dalam mengatasi masalah yang dihadapi orang tersebut, (3) informasi verbal, yaitu kemampuan seseorang untuk menggunakan bahasa lisan maupun bahasa tulisan dalam mengungkapkan suatu masalah, (4) Sikap, yaitu kecenderungan untuk menerima atau menolak suatu objek, (5) keterampilan motorik, yaitu kemampuan seseorang untuk mengkoordinasikan gerakan otot secara teratur dan lancar dalam keadaan sadar (Gagne dkk, 2010: 30).

Reigeluth mengemukakan bahwa hasil pembelajaran secara umum dapat dikategorisasi menjadi tiga indikator, yaitu (1) efektivitas pembelajaran yang biasanya diukur dari tingkat keberhasilan peserta didik dari berbagai sudut, (2) efisiensi pembelajaran, yang biasanya diukur dari waktu belajar dan/atau biaya pembelajaran, dan (3) daya tarik pembelajaran yang selalu diukur dari tendensi peserta didik ingin belajar secara terus menerus (Reigeluth, 2011: 36-52).

Dalam penelitian ini akan menggunakan adaptasi dari hasil revisi taksonomi Bloom, sehingga akan berpengaruh pada rumusan hasil belajar yang hendak dicapai. Reigeluth mengatakan bahwa hasil belajar dirumuskan sebagai perilaku yang dapat diamati yang menunjukkan kemampuan yang dimiliki seseorang (Reigeluth, 2011: 4-8). Penilaian dan belajar menurut Shavelson, Baxter dan Pine, merupakan dua sisi mata uang. Hasil penilaian dapat dipergunakan untuk memberikan informasi bagaimana sebaiknya pendidik dalam mengelola pembelajaran dan bagaimana cara peserta didik harus belajar (Shavelson dkk, 2007: 2)

Dengan demikian yang dimaksud hasil belajar PKn adalah kemampuan yang dicapai peserta didik setelah menyelesaikan pembelajarannya. Hasil belajar PKn dalam penelitian ini akan diukur dengan menggunakan tes objektif

\section{METODOLOGI PENELITIAN}

\section{Subyek Penelitian}

Penelitian tindakan ini dilaksanakan pada peserta didik kelas VII semester pertama tahun 2013.

\section{Prosedur Dasar Pengembangan Tindakan}

Langkah-langkah penelitian ini mengikuti prinsip-prinsip dasar yang berlaku yakni menggunakan prinsip daur ulang. Secara umum tahapan dalam penelitian ini dapat dibagi menjadi dua, 
yaitu (1) tahap perencanaan tindakan, (2) tahap pelaksanaan tindakan. Pada tahap pelaksanaan tindakan ada sejumlah kegiatan yang dilakukan secara daur ulang, mulai dari tahap orientasi, perencanaan, pelaksanaan tindakan, observasi, refleksi, dan revisi (McNaff, 2002; Kemmis, 2010 dan Hopkins, 2003).

\section{Pelaksanaan Tindakan}

Pelaksanaan program tindakan dalam meningkatkan hasil belajar PKn melalui strategi pembelajaran cooperative Learning Tipe TGT, akan dilakukan dengan mempertimbangkan perkembangan situasi sosial kelas. Hal ini sesuai dengan karakteristik penelitian tindakan, bahwa rencana program tindakan berkembang dan berubah sesuai dengan tuntutan situasi laporan (McNifft,2002; Hopkins, 2003). Adapun alasan (rasional) pelaksanaan pembelajaran Cooperative Learning Tipe TGT dalam 3 siklus, karena diasumsikan dalam 3 siklus peningkatan hasil belajar dapat terwujud. Namun apabila asumsi ini kurang tepat, maka putaran/siklus akan ditambah/dikurangi sesuai tujuan.

Untuk lebih jelasnya rancangan siklus dapat dilihat seperti di bawah ini : 


\section{Rancangan Dasar Pengembangan Pelaksanaan Tindakan}

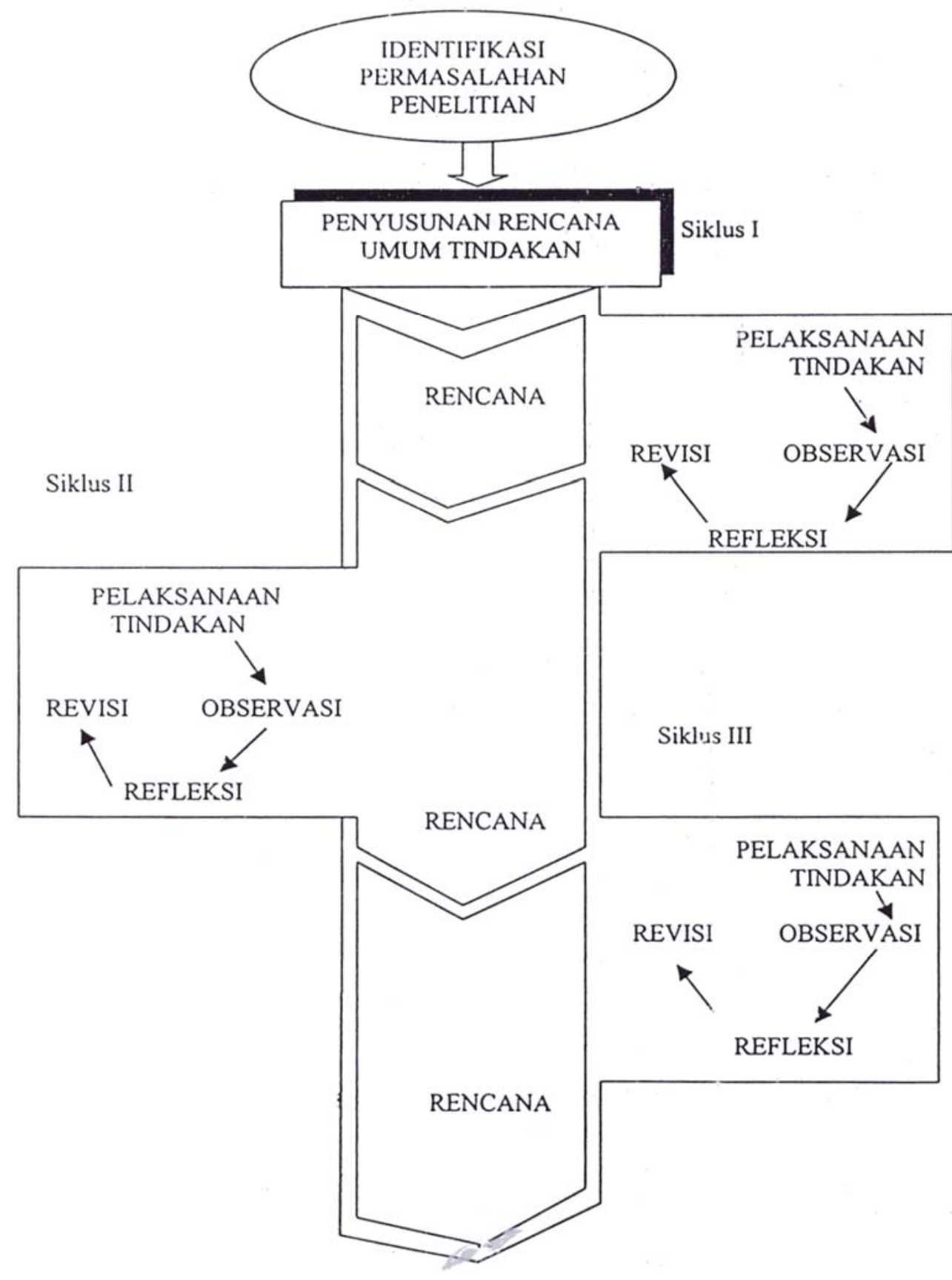




\section{Teknik Pengumpulan Data}

Dalam penelitian ini pengumpulan data mengenai pelaksanaan dan hasil program tindakan akan dilakukan dengan :

1) Lembar observasi

Instrumen ini dirancang sendiri oleh tim peneliti. Lembar observasi ini digunakan untuk mengumpulkan data mengenai unjuk kerja pendidik dan aktivitas belajar peserta didik selama tindakan dalam pembelajaran dengan menggunakan Cooperative Learning Tipe TGT

2) Instrumen motivasi belajar

Digunakan untuk menjaring data hasil belajar PKn, dari siklus I sampai terakhir, sehingga jelas peningkatannya.

3) Field note (catatan lapangan)

Digunakan untuk menjaring data yang berkembang selama pelaksanaan tindakan, dan sebagai bahan perbandingan untuk validitas data.

\section{Analisis Data}

Dalam penelitian tindakan kelas, proses analisis data sudah dilakukan sebelum program tindakan, sehingga analisis data berlangsung dari awal sampai akhir dari pelaksanaan program tindakan (Suwarsih, 2001, McNifft, 2002).

Secara rinci prosedur dan pengolahan data dapat dijelaskan sebagai berikut:

1) Pengumpulan, kodifikasi dan kategori data

2) Validasi data

2.1. Triangulasi data

2.2. Audit trail

2.3. Member-check

3) Interpretasi

\section{HASIL PENELITIAN}

\section{Deskripsi Data Pelaksanaan Tindakan} Melalui Cooperative Learning Tipe TGT

Berdasarkan data awal sebelum dilakukan penelitian, tes awal nilai ratarata peseta didik sebesar 55,6, sedangkan $\mathrm{KKM}=70$. Untuk jelasnya lihat tabel di bawah ini. 
Tabel 1

Daftar Nilai Pre Test Peserta Didik Kelas VII C

KKM 70

\begin{tabular}{|c|c|c|}
\hline КЕLOMPOK & NAMA SISWA & TES AWAL \\
\hline \multirow{3}{*}{1} & Martgu Pardede & 58 \\
\hline & Dody Yoga & 50 \\
\hline & Hendrik Alamsyah & 50 \\
\hline \multirow{3}{*}{2} & Agung K. & 55 \\
\hline & Dudi K. & 50 \\
\hline & Tomi Irawan & 50 \\
\hline \multirow{3}{*}{3} & Gita Rismaya & 57 \\
\hline & Khilda & 66 \\
\hline & M. Fadil & 55 \\
\hline \multirow{3}{*}{4} & Elva Silviasari & 55 \\
\hline & Masitoh & 50 \\
\hline & Suryana & 60 \\
\hline \multirow{3}{*}{5} & Neni Ulfiah & 60 \\
\hline & Juwarsih & 55 \\
\hline & Egi Permadi & 55 \\
\hline \multirow{3}{*}{6} & Nenti Perwati & 55 \\
\hline & Resa Ayu & 53 \\
\hline & Eko P. & 60 \\
\hline \multirow{3}{*}{7} & Ratna Dila & 58 \\
\hline & Isnawati & 57 \\
\hline & Agus Budi S. & 60 \\
\hline \multirow{3}{*}{8} & Putri Meilani & 60 \\
\hline & Istiwitani P. & 56 \\
\hline & Rahmat & 50 \\
\hline \multirow{3}{*}{9} & Gina Kurnia & 60 \\
\hline & Siti Fadilla & 56 \\
\hline & Agus Juwana & 52 \\
\hline \multirow{3}{*}{10} & Neng Winda & 57 \\
\hline & Marwiyah & 55 \\
\hline & Yogi Pradipta & 53 \\
\hline \multicolumn{2}{|r|}{ Jumlah } & 1168 \\
\hline & $\overline{\mathbf{X}}$ & 55,6 \\
\hline
\end{tabular}


Pada siklus I dengan menggunakan Cooperative Learning Tipe Team Game Tournament (TGT), jumlah nilai secara keseluruhan sebesar 1.789 , dan nilai ratarata peserta didik sebesar 62,6 dengan kenaikan sebesar 12,64\% (dibandingkan dengan skor awal (pre test).

Pada siklus II dengan menggunakan Cooperative Learning Tipe TGT, jumlah nilai secara keseluruhan sebesar 2.222, dengan nilai rata-rata sebesar 74,07, dengan kenaikan sebesar 33,21\%.

Siklus III dengan menggunakan Cooperative Learning Tipe TGT, jumlah nilai secara keseluruhan sebesar 2.488, dengan nilai rata-rata sebesar 82,9 , dengan kenaikan sebesar 49,16\%. Untuk lebih jelasnya dapat dilihat pada tabel 2 di bawah ini.

Tabel 2

Daftar Nilai Pre Test Dan Post Test Tiap Siklus

Peserta Didik Kelas VII C

KKM 70

\begin{tabular}{|c|l|c|c|c|c|}
\hline \multirow{3}{*}{ Kelompok } & \multicolumn{1}{|c|}{ Nama siswa } & $\begin{array}{c}\text { Tes } \\
\text { awal }\end{array}$ & $\begin{array}{c}\text { Siklus } \\
\text { I }\end{array}$ & $\begin{array}{c}\text { Siklus } \\
\text { II }\end{array}$ & $\begin{array}{c}\text { Siklus } \\
\text { III }\end{array}$ \\
\hline \multirow{3}{*}{1} & Martgu Pardede & 58 & 63 & 71 & 81 \\
\cline { 2 - 6 } & Dody Yoga & 50 & 65 & 70 & 80 \\
\cline { 2 - 6 } & Hendrik Alamsyah & 50 & 63 & 72 & 75 \\
\hline \multirow{3}{*}{2} & Agung K. & 55 & 62 & 70 & 85 \\
\cline { 2 - 7 } & Dudi K. & 50 & 60 & 75 & 83 \\
\cline { 2 - 7 } & Tomi Irawan & 50 & 55 & 65 & 80 \\
\hline \multirow{3}{*}{3} & Gita Rismaya & 57 & 63 & 75 & 85 \\
\cline { 2 - 7 } & Khilda & 66 & 71 & 80 & 90 \\
\cline { 2 - 7 } & M. Fadil & 55 & 65 & 76 & 86 \\
\hline \multirow{3}{*}{4} & Elva Silviasari & 55 & 60 & 75 & 80 \\
\cline { 2 - 7 } & Masitoh & 50 & 60 & 75 & 78 \\
\cline { 2 - 7 } & Suryana & 60 & 63 & 73 & 78 \\
\hline \multirow{3}{*}{5} & Neni Ulfiah & 60 & 65 & 75 & 85 \\
\cline { 2 - 7 } & Juwarsih & 55 & 68 & 78 & 82 \\
\cline { 2 - 7 } & Egi Permadi & 60 & 71 & 82 \\
\hline
\end{tabular}




\begin{tabular}{|c|c|c|c|c|c|}
\hline Kelompok & Nama siswa & $\begin{array}{c}\text { Tes } \\
\text { awal }\end{array}$ & $\begin{array}{c}\text { Siklus } \\
\text { I }\end{array}$ & $\begin{array}{c}\text { Siklus } \\
\text { II }\end{array}$ & $\begin{array}{c}\text { Siklus } \\
\text { III }\end{array}$ \\
\hline \multirow{3}{*}{6} & Nenti Perwati & 55 & 60 & 72 & 82 \\
\hline & Resa Ayu & 53 & 60 & 73 & 78 \\
\hline & Eko P. & 60 & 65 & 78 & 85 \\
\hline \multirow{3}{*}{7} & Ratna Dila & 58 & 63 & 73 & 82 \\
\hline & Isnawati & 57 & 62 & 75 & 85 \\
\hline & Agus Budi S. & 60 & 67 & 78 & 90 \\
\hline \multirow{3}{*}{8} & Putri Meilani & 60 & 65 & 75 & 85 \\
\hline & Istiwitani P. & 56 & 61 & 71 & 80 \\
\hline & Rahmat & 50 & 60 & 76 & 80 \\
\hline \multirow{3}{*}{9} & Gina Kurnia & 60 & 65 & 72 & 82 \\
\hline & Siti Fadilla & 56 & 66 & 76 & 85 \\
\hline & Agus Juwana & 52 & 60 & 78 & 86 \\
\hline \multirow{3}{*}{10} & Neng Winda & 57 & 62 & 72 & 86 \\
\hline & Marwiyah & 55 & 60 & 76 & 85 \\
\hline & Yogi Pradipta & 53 & 60 & 78 & 87 \\
\hline \multicolumn{2}{|r|}{ Jumlah } & 1668 & 1879 & 2222 & 2488 \\
\hline \multicolumn{2}{|r|}{$\overline{\mathbf{X}}$} & 55,6 & 62,6 & 74,07 & 82,9 \\
\hline \multicolumn{2}{|r|}{$\%$} & & $12,64 \%$ & $33,21 \%$ & $49,16 \%$ \\
\hline
\end{tabular}

Adapun rata-rata tiap orang dan prosentase peningkatan tiap peserta didik dapat dilihat pada tabel di bawah ini.

Tabel 3

Daftar Nilai Pre Test dan Post Test Serta Prosentase

Peserta Didik Kelas VII C

KKM 70

\begin{tabular}{|c|l|c|c|c|c|c|c|}
\hline \multirow{2}{*}{ Kelompok } & Nama siswa & $\begin{array}{c}\text { Tes } \\
\text { awal }\end{array}$ & $\begin{array}{c}\text { Siklus } \\
\text { I }\end{array}$ & $\begin{array}{c}\text { Siklus } \\
\text { II }\end{array}$ & $\begin{array}{c}\text { Siklus } \\
\text { III }\end{array}$ & $\overline{\mathbf{X}}$ & $\begin{array}{c}\text { \% } \\
\text { Peningkatan } \\
\text { Tiap Orang }\end{array}$ \\
\hline \multirow{2}{*}{1} & Martgu Pardede & 58 & 63 & 71 & 81 & 71,67 & $23,57 \%$ \\
\cline { 2 - 8 } & Dody Yoga & 50 & 65 & 70 & 80 & 71,67 & $43,34 \%$ \\
\cline { 2 - 8 } & Hendrik A. & 50 & 63 & 72 & 75 & 70,00 & $40,00 \%$ \\
\hline 2 & Agung K. & 55 & 62 & 70 & 85 & 72,33 & $31,51 \%$ \\
\hline
\end{tabular}




\begin{tabular}{|c|c|c|c|c|c|c|c|}
\hline & Dudi K. & 50 & 60 & 75 & 83 & 72,67 & $45,34 \%$ \\
\hline & Tomi Irawan & 50 & 55 & 65 & 80 & 66,67 & $32,00 \%$ \\
\hline \multirow{3}{*}{3} & Gita Rismaya & 57 & 63 & 75 & 85 & 74,33 & $30,40 \%$ \\
\hline & Khilda & 66 & 71 & 80 & 90 & 80,33 & $21,71 \%$ \\
\hline & M. Fadil & 55 & 65 & 76 & 86 & 75,67 & $37,58 \%$ \\
\hline \multirow{3}{*}{4} & Elva Silviasari & 55 & 60 & 75 & 80 & 71,67 & $30,31 \%$ \\
\hline & Masitoh & 50 & 60 & 75 & 78 & 71,00 & $42,00 \%$ \\
\hline & Suryana & 60 & 63 & 73 & 78 & 71,33 & $18,88 \%$ \\
\hline \multirow{3}{*}{5} & Neni Ulfiah & 60 & 65 & 75 & 85 & 75,00 & $25,00 \%$ \\
\hline & Juwarsih & 55 & 68 & 78 & 82 & 76,00 & $38,18 \%$ \\
\hline & Egi Permadi & 55 & 60 & 71 & 82 & 71,00 & $29,09 \%$ \\
\hline \multirow{3}{*}{6} & Nenti Perwati & 55 & 60 & 72 & 82 & 71,33 & $29,69 \%$ \\
\hline & Resa Ayu & 53 & 60 & 73 & 78 & 70,33 & $32,70 \%$ \\
\hline & Eko P. & 60 & 65 & 78 & 85 & 76,00 & $26,67 \%$ \\
\hline \multirow{3}{*}{7} & Ratna Dila & 58 & 63 & 73 & 82 & 72,67 & $25,29 \%$ \\
\hline & Isnawati & 57 & 62 & 75 & 85 & 74,00 & $29,82 \%$ \\
\hline & Agus Budi S. & 60 & 67 & 78 & 90 & 78,33 & $30,55 \%$ \\
\hline \multirow{3}{*}{8} & Putri Meilani & 60 & 65 & 75 & 85 & 75,00 & $25,00 \%$ \\
\hline & Istiwitani P. & 56 & 61 & 71 & 80 & 70,67 & $26,20 \%$ \\
\hline & Rahmat & 50 & 60 & 76 & 80 & 72,00 & $44,00 \%$ \\
\hline \multirow{3}{*}{9} & Gina Kurnia & 60 & 65 & 72 & 82 & 73,00 & $21,67 \%$ \\
\hline & Siti Fadilla & 56 & 66 & 76 & 85 & 75,67 & $35,12 \%$ \\
\hline & Agus Juwana & 52 & 60 & 78 & 86 & 74,67 & $43,60 \%$ \\
\hline \multirow{3}{*}{10} & Neng Winda & 57 & 62 & 72 & 86 & 73,33 & $28,65 \%$ \\
\hline & Marwiyah & 55 & 60 & 76 & 85 & 73,67 & $33,94 \%$ \\
\hline & Yogi Pradipta & 53 & 60 & 78 & 87 & 75,00 & $41,51 \%$ \\
\hline \multicolumn{2}{|c|}{ Jumlah } & 1.668 & 1.879 & 2.222 & 2.488 & $\begin{array}{c}2196 \\
33\end{array}$ & \\
\hline \multicolumn{2}{|r|}{$\overline{\mathbf{X}}$} & 55,6 & 62,6 & 74,07 & 82,9 & $\begin{array}{c}73,21 \\
1\end{array}$ & \\
\hline \multicolumn{2}{|r|}{$\%$} & & $12,64 \%$ & $\begin{array}{c}33,21 \\
\%\end{array}$ & $\begin{array}{c}49,16 \\
\%\end{array}$ & $\begin{array}{c}31,67 \\
\%\end{array}$ & \\
\hline
\end{tabular}

Dengan demikian hasil belajar PKn meningkat sebesar 49,16\% dengan menggunakan Cooperative Learning Tipe TGT.

Berdasarkan hasil penelitian bahwa peserta didik yang mendapat ranking, dalam TGT, ternyata mendapat skor tertinggi dalam tes tiap siklus.

\section{KESIMPULAN}

Strategi pembelajaran Cooperative Learning Tipe Team Game Tournament (TGT) dapat meningkatkan hasil belajar PKn sebesar 49,16\%. Untuk itu strategi pembelajaran ini dapat menjadi pilihan 
untuk mendorong kemampuan siswa dalam meningkatkan hasil belajar mereka.

Lebih dari itu, strategi pembelajaran ini dapat menjadikan siswa lebih mandiri, terlatih, fleksibel, sehingga mendukung pengembangan pengetahuan, sikap, moral dan keterampilan mereka. Dengan demikian pendidikan kewarganegaraan tidak menjadi pelajaran yang membosankan dan terkesan kaku.

\section{DAFTAR PUSTAKA}

Anderson, Lorin W. and David R. Kratwohl. Taxonomy for Learning Teaching and Assessing, A Revision of Bloom's Taxonomy of Education Objectives. New York: Addison Wesley Logman, Inc., 2001.

Arends, Richard I. Learning to Teach. Singapore: McGraw-Hill, Fourth Edition. 2008.

CP Phaplin. Kamus Lengkap Psikologi. Jakarta: Rajawali Pers. 2009.

Davies, Ivor K. Pengelolaan Belajar.. Jakarta: Rajawali. 2006.

Dimyati dan Mudjiono. Belajar dan Pembelajaran. Jakarta: Rineka Cipta. 2002

Djahiri, A Kosasih, Dasar-dasar Metodologi Pengajaran, Bandung: Lab Pengajaran PMP IKIP Bandung. 1992.

Gagne, RM; Lislei J Briggs and Walter W Wager. Principles of Instructional
Design. New York: Holt Rinehart and Winston. 2010.

Gagne, Robert $\mathrm{M}$, etc. Principles of Instructional Design. New York: Holt Rinehart and Winston. 2010.

Gredler Margareth, E. Bell. Belajar dan Pembelajaran. Jakarta: Rajawali. 2011.

Nasution, S. Berbagai Pendekatan dalam Proses Belajar Mengajar. Jakarta: PT Bina Aksara. 2004.

Popham, James W. Teknik Mengajar Secara Sistematis. Solo: Rineka Cipta. 2002.

Reigeluth, Chrates M. Instructional-Design Theories and Model: A New Paradigm of Instructional Theory. Hillsdale, New York: Lawrence Earlbaum. 2011.

Romiszoeski, A. Design Instructional System. London: Kogan Page Ltd. 2011.

Romiszowski, A. Instructional Design System: Decision Making in Course Planning and Curriculum Design. London: Kogan. 2011

Santoso, Soegeng. Problematik Pendidikan dan Cara Pemecahannya. Jakarta: Kreasi Pena Bading. 2000.

Seels, Barbara B and Richey, Rita C. Instructional Technology: The Definitions and Domain of The Field. Washington DC : Association for Educational Communication and Technology. 2004.

Slavin, Robert E. Cooperative Learning, Maryland: John Hopkins University, 2010. 
JURNAL ILMIAH MIMBAR DEMOKRASI

VOLUME 13, NOMOR 1, OKTOBER 2013

Slavin, Robert E. Cooperative Learning: Theory, Research and Practice, London: Allyman Bacon, 2010.

Stahl, Robert J. Cooperative Learning in Social Studies, New York: Kane Publishing Service Inc, 2004.
Solihatin, Etin. Cooperative Learning: Analisis Model Pembelajaran IPS, Jakarta: PT Bumi Aksara, 2012.

Solihatin, Etin. Strategi Pembelajaran $P P K N$, Jakarta: PT Bumi Aksara, 2012. 